\title{
SOCIAL SECURITY, SOCIAL WELFARE AND THE AGING POPULATION
}

\author{
Rowena A. Pecchenino* and Kelvin R. Utendorf† \\ *Department of Economics \\ Michigan State University \\ East Lansing, Michigan 48824 \\ (517) 353-6621 \\ (517)432-1068 (fax) \\ rowenap@pilot.msu.edu \\ †Woodbridge, VA 22192 \\ (703) 492-0709 \\ kruman@Radix.net
}

April 1998

Revised January 1999

This study examines the effects of pay-as-you-go social security programs in aging economies when the middle-aged both educate their dependent children and subsidize the retirement of the old. Using an overlapping generations framework in which agents are three-period lived but timing of death in the third period is uncertain, we analyze the effects of social security tax schemes, under various demographic assumptions, on capital accumulation, education expenditures, social welfare, and economic growth. We find that in many cases social security crowds out education, and reduces economic growth and social welfare.

JEL Classification Numbers: D9, H2, I2

Keywords: Social Security, Education, Endogenous growth

Pecchenino is grateful for the hospitality of the International Centre for Economic Research, Turin, Italy, where much of the work was accomplished. We are also grateful to the seminar participants at Michigan State University, the Universita di Torino, and the University of Western Ontario for their comments. All remaining errors are the authors' alone. 


\section{Introduction}

In the last decades of the twentieth century the economies of the industrialized nations have seen their populations age and their trend rates of growth slow. Either phenomenon alone could place the viability of unfunded social security schemes in doubt; both together could place such schemes in crisis (Weaver, 1992). This premonition of crisis motivated the 1994-1996 Advisory Council on Social Security to consider radical changes to the Social Security system to prevent the necessity of raising taxes to keep the system in actuarial balance. ${ }^{1}$ The political feasibility of tax increases, largely eschewed by the Advisory Council and in the political debate that has followed, is certainly open to question. Yet, as Auerbach and Kotlikoff (1990) note, the retirees who benefit from these tax increases are a powerful political force. ${ }^{2}$ Before taxes or the social security system itself are changed we must consider the long-term effects of changes to the social security system not only on the politically active old but on society as a whole.

To assess the viability of a social security system one cannot examine this single intergenerational transfer in isolation, but must examine the panoply of intergenerational transfers that defines an individual's life. Parents make inter vivos transfers not only to their aged parents by subsidizing their parents' retirement via the payment of social security taxes, but also to their children by educating them. Aged parents leave bequests to their adult children. Clearly, the needs of aged parents and young children compete. What this competition implies for the future of social security is the question we seek to answer.

Using an overlapping generations framework, as developed in the works of Allais (1947), Samuelson (1958) and Diamond (1965), in which agents are three- period lived but the timing of death in the third period is uncertain, we analyze the effects of a number of social security tax

\footnotetext{
1 Aaron and Burtless (1989) estimated that social security taxes will have to rise by as much as $23 \%$ to keep the system in the United States solvent over the next 75 years, making social security an even large component of public spending.

2 Congleton and Shugart (1990), in contrast, find that most changes in social security benefits can be traced to changes in constraints faced by the median voter rather than the political power of special interest groups.
} 
schemes, under various demographic assumptions, on physical capital accumulation, the education provided to children by their parents, social welfare, and economic growth.

In common with many models of social security, our model looks at social security as a mechanism to effect intergenerational exchange. ${ }^{3}$ However, our model differs from many models of pay-as-you-go social security systems (see, for example, Samuelson (1958), Diamond, (1977), Imrohoroglu, Imrohoroglu and Joines (1992), among others) in that these models ignore child welfare issues when assessing the effects of various social security programs and/or tax rates on capital accumulation and social welfare. Other work, while not ignoring children, assumes that expenditures on children are entirely tax financed, as in Wildasin (1991), or claims that human capital formation is independent of direct expenditures on children as in Sala-i-Martin (1992). Glomm and Ravikumar (1992) make education decisions central to their analysis, but abstract from any spillovers of these decisions on the utility of the aged. Caballé (1995) also makes education expenditures central to his analysis, and altruistically links parents to children throughout their lives. But, in his model children are not called upon to fund their parents' retirement. In our model the interactions between social security programs and parents' decisions concerning their children's education play a central role through the effects of human capital formation on labor productivity, and through this channel on economic growth. ${ }^{4}$ Our analyses show clearly that social security can crowd out education, and, thereby, reduce capital accumulation, growth, and social welfare.

The rest of the paper is organized as follows. In section II we develop the general model. In section III we define the equilibrium generically, and then analyze the steady-state equilibrium in section IV, and equilibrium balanced growth paths, under specific functional form assumptions, in section $\mathrm{V}$. In section $\mathrm{V}$ special attention is paid to the welfare implications of

\footnotetext{
${ }^{3}$ See Kotlikoff (1987) and Diamond (1977) for discussion of the various rationales for social security.

${ }^{4}$ For other models in which growth is generated via human capital development see Lucas (1988) and Caballé (1995).
} 
changes in tax policies and demographics. We conclude the paper in section VI with a summary of our findings and a discussion of their implications.

\section{The Environment}

Consider an infinitely-lived economy comprised of identical three-period lived agents, perfectly competitive firms, and a government. At each date $t=1,2,3, \ldots$, a new generation (called generation $\mathrm{t}$ ) of $N(t)$ agents is born. Assume $N(t)=(1+n(t)) N(t-1), N(0)$ given.

\section{Consumers}

Agents in the first period of their lives, the young, are endowed with one unit of time that they combine with the education provided by their parents to develop their human capital. This education is an in kind inter vivos transfer; it can neither be transformed into physical capital nor consumption. Such parental educational inputs have been shown to be a crucial determinant of children's educational attainment (Black, 1998), while other forms of educational spending have not been shown consistently to have such positive effects (Hanushek, 1997). Agents in the second period of their lives, the middle-aged, supply their effective labor, the product of their one unit of time and their human capital developed in youth, inelastically to firms. ${ }^{5}$ They divide their income between educating their $1+n$ children, current consumption, saving for consumption when old, and payment of social security taxes. Agents in the final period of their lives, the old, supply their savings inelastically to firms and consume their social security benefits and the their accumulated savings. With probability $p(t)$ an old agent born at date $t$ will live throughout old

\footnotetext{
${ }^{5}$ Reimers (1992) suggests that social security programs lead to intertemporal substitution of labor so that agents work more while young, and retire earlier than in the absence of a social security scheme. We choose to model this as an inelastic labor supply during middle age and then forced retirement at the commencement of old age. Because we have abstracted from issues concerning labor supply choice, we also ignore the issues of social security as a way to improve the average level of skill in the economy addressed by Sala-i-Martin (1992).
} 
age, and with probability $1-p(t)$ an old agent will die at the onset of old age. ${ }^{6}$ If an agent dies at the onset of old age, his savings are bequeathed to his children.

Let the representative member of generation $t$ 's preferences be represented by

$$
U(t)=u\left(c_{t}(t+1)\right)+\beta p(t) v\left(c_{t}(t+2)\right)+\delta(1+n(t+1)) h(e(t+1))
$$

where $u(), v()$ and $h()$ are all twice continuously differentiable, increasing, concave functions, $c_{t}(t+1)$ is consumption by a member of generation $t$ when middle-aged, and $c_{t}(t+2)$ is consumption by a member of generation $t$ when old. Further, $\beta>0$ is the rate of time preference. While children do not get utility while being educated, parents get utility from educating them. Their utility is derived from their "love of" or "duty to" their children rather than any personal return they may reap from their investment or any other strategic motive (see Cremer, et al., 1992). This inter vivos bequest motive encompasses the lifetime bequest motive. ${ }^{7}$ Since agents do not know when they will die, additional unintentional bequests may be forthcoming. ${ }^{8}$

Assuming exogenous fertility and an altruistic bond between parents and their children runs counter to the empirical findings of Cigno and Rosati (1996). They find that parents are self-interested and choose their saving and fertility without regard to their offspring. Our model differs from theirs in that in ours there is uncertainty about the timing of death, hence we cannot rule out unintentional end-of-life bequests (whether there is a bequest motive or not), and is general rather than partial equilibrium in nature, while abstracting from the fertility choice. However, if we alter our model by removing the altruistic bond between parents and children (by

\footnotetext{
${ }^{6}$ In this model agents face uncertainty about the time of death but not about the maximum possible length of life. Thus, agents may die before they have exhausted their non-social security wealth, but not vice versa.

${ }^{7}$ While other models endogenize both expenditures on children and bequests, e.g. Nishmura and Zhang (1992, 1995), they assume that income and interest rates are exogenous. In our model, where wages and interest rates are endogenous, introducing an end-of-life bequest motive makes the analysis intractable.

${ }^{8}$ The assumption of unintentional rather than altruistic end-of-life bequests is consistent with the empirical findings of numerous researchers: see Hurd (1989, 1990), Auerbach, et al. (1992), and Borsh-Supan (1993), as well as the finding by Altonji, et al. (1992) that parents and their adult children are not altruistically linked. But, other research finds an operative bequest motive (Hamermesh and Menchik (1987) and Hurd (1995)). In contrast, Laitner and Juster (1996) find support for intergenerational altruism but note that it is not the major explanation for saving.
} 
assuming $\delta=0$ ) and replacing it with intergenerational education loans, then the same results can be derived under similar conditions on the tax function, introduced below. Thus, while the bond between parent and child is an integral part of our model, our steady-state results generalize to a model where altruism plays no role. ${ }^{9}$

If a parent invests $e(t+1)$ in each child's education, each child will enter the labor force with $h(e(t+1))$ units of human capital, since all of a child's time will be spent gaining an education. That is, the education production function converts the unit of a child's time combined with the $e(t+1)$ units of education expenditure into $h(e(t+1))$ units of human capital. Thus, the utility a parent at date $t+1$ receives from educating his dependent children is $\delta h(e(t+1))$, where and $\delta$ is the weight placed on the utility a parent receives from educating his children. $^{10}$

If an agent dies at the onset of his old age, his accumulated savings, $(1+r(t+1)) s(t)$, are bequeathed in full to his heirs. To maintain the representative agent formulation, bequests

(2) $B(t+1)=\frac{(1-p(t-1))(1+r(t+1)) s(t)}{1+n(t)}$

are equally divided among all the middle aged. Thus, the bequest dependent wealth distribution is uniform, as in Hubbard and Judd (1987). This assumption allows us to conduct a representative agent analysis, and restricts uncertainty to the timing of death alone, which allows us to focus more clearly on the effects of changes in expected longevity.

\footnotetext{
${ }^{9}$ This model and the results it implies are available from the authors upon request.

${ }^{10}$ Our formulation is in contrast to Barro (1974) and other explicitly or implicitly dynastic models, such as Ehrlich and Lui (1991), in which parents internalize the lifetime utility of their children. In these models the effects of changes in taxes are negated via changes in bequests, and so are ill-suited to analyzing social security schemes. Our formulation is similar to the parent-child utility linkage assumed in Boldrin (1993).
} 
Firms

The firms are perfectly competitive profit maximizers that produce output using the constant returns to scale production function $Y(t+1)=A F(K(t+1), H(t+1))$, where $F_{K}>0, F_{H}>0, F_{K H}>0, F_{K K}<0, F_{H H}<0 . K(t+1)$ is the capital stock at $t+1$ which depreciates fully in the production process. $H(t+1)$ is the effective labor input at $t+1$, $H(t+1)=N(t) h(e(t))$, where $N(t)$ is labor hours, the productivity of which is augmented by the worker's human capital, $h(e(t)) . A$ is a time independent productivity scalar. The intensive form production function is $y(t+1)=A f(k(t+1), h(t+1))$, where lower case variables are per capita values.

The individual firm takes wages and rental rates as given. It hires effective labor and capital until their marginal products equal their factor prices

(3) $A f_{h}(k(t+1), h(t+1))=w(t+1)$

(4) $A f_{k}(k(t+1), h(t+1))=r(t+1)$.

\section{The Government}

The government in this economy imposes a proportional wage tax, $\tau$, on the middle-aged.

The wage tax rate is expressed as a nondecreasing function of the aged-dependency ratio,

$\frac{N(t) p(t)}{N(t+1)}=\frac{p(t)}{1+n(t)}$, the ratio of old agents who receive social security benefits, to middle aged agents paying social security taxes. ${ }^{11}$ The government must fully fund all expenditures with tax

We adopt it specifically so that we can study the effect changes in the social security system, in response to demographic changes, have on investment in education.

${ }^{11}$ This parameterization is an attempt to impose a functional relationship on the political process under which taxes are set. The relationship is motivated by the empirical finding that the social security tax rate and the aged-dependency ratio are strongly positively correlated, and by the fact that the Social Security Administration's Office of the Chief Actuary uses the aged-dependency ratio as a proxy for the cost of the system. Further, this functional relationship is consistent with the empirical finding by Poterba and Summers (1986) that as the population ages the costs of social security programs rise. It is also consistent with Aaron and Burtless's (1989) finding that the US Congress tends to legislate changes in social security 
receipts: it must maintain a balanced budget. Thus, total social security benefits paid, $T(t+2)$, must equal total revenues from wage taxes

$$
N(t) p(t) T(t+2)=N(t+1) h(e(t+1)) w(t+2) \tau(),
$$

implying that

(5) $T(t+2)=\frac{(1+n(t+1)) h(e(t+1)) w(t+2) \tau()}{p(t)}$.

\section{Equilibrium}

Definition: A competitive equilibrium for this economy is a sequence of prices

$\{w(t+1), r(t+1)\}_{t=0}^{\infty}$ a sequence of allocations $\left\{c_{t}(t+1), c_{t}(t+2)\right\}_{t=0}^{\infty}$ and a sequence of education expenditures and physical capital stocks, $\{e(t-1), k(t)\}_{t=0}^{\infty}, e(-1)>0$ and $k(0)>0$ given, such that given these prices and allocations, agents' utility is maximized, firms' profits are maximized, the government budget constraint is satisfied, and markets clear.

The representative agent born at time $t$ takes as given his human capital, $h(e(t))$, the wage faced in middle age, $w(t+1)$, the return on saving when old, $r(t+2)$, the tax rate function, $\tau\left(p(t-1) /(1+n(t)), \tau^{\prime}()>0\right.$, social security benefits, $T(t+2)$, bequests from his parents, $B(t+1)$, and chooses saving, $s(t+1)$, and expenditures on each of his children's educations, $e(t+1)$, to maximize (1) subject to

(6) $c_{t}(t+1)=h(e(t)) w(t+1)\left(1-\tau\left(\frac{p(t-1)}{1+n(t)}\right)\right)-s(t+1)-(1+n(t+1)) e(t+1)+B(t+1)$

(7) $c_{t}(t+2)=(1+r(t+2)) s(t+1)+T(t+2)$

where constraint (6) encompasses the assumption that bequests are allocated equally across all members of a generation.

taxes or benefits to keep the system in balance. This suggests a tax schedule that is a function of the ageddependency ratio. 
Substituting constraints (6) and (7) into the objective function (1) and maximizing yields the first-order conditions of the agent's problem with respect to saving and education expenditures, respectively:

$$
\begin{aligned}
& -u^{\prime}()+\beta p(t)(1+r(t+2)) v^{\prime}()=0 \\
& -u^{\prime}()+\delta h^{\prime}()=0
\end{aligned}
$$

The goods market clears when demand for goods equals supply of goods, so saving today determines the capital stock tomorrow:

(10) $s(t)=(1+n(t)) k(t+1)$.

\section{The Steady State}

Assume that all parameters are time independent so that $p(t)=p$ for all $t$, etc. Steadystate equilibrium is represented by

$$
\begin{aligned}
& -u^{\prime}\left(c^{m}\right)+\beta p(t)(1+r(t+2)) v^{\prime}\left(c^{o}\right)=0 \\
& -u^{\prime}\left(c^{m}\right)+\delta h^{\prime}(e)=0
\end{aligned}
$$

where

$$
\begin{aligned}
& c^{m}=A f_{h}(k, h(e)) h(e)\left(1-\tau\left(\frac{p}{1+n}\right)\right)+(1-p) A f_{k}(k, h(e)) k-(1+n)(k+e) \\
& c^{o}=A f_{k}(k, h(e)) k(1+n)+\left(\frac{1+n}{p}\right) A f_{h}(k, h(e)) h(e) \tau\left(\frac{p}{1+n}\right)
\end{aligned}
$$

Totally differentiating (11) and (12) with respect to the tax rate and demographic parameters yields the following system:

$$
\begin{gathered}
{\left[\begin{array}{rr}
-u^{\prime \prime} c_{k}^{m}+\beta p\left[f_{k k} v^{\prime}+f_{k} v^{\prime \prime} c_{k}^{o}\right] & -u^{\prime \prime} c_{e}^{m}+\beta p\left[f_{k h} h^{\prime} v^{\prime}+f_{k} v^{\prime \prime} c_{e}^{o}\right] \\
-u^{\prime \prime} c_{k}^{m} & -u^{\prime \prime} c_{e}^{m}+\delta h^{\prime \prime}
\end{array}\right]\left[\begin{array}{l}
d k \\
d e
\end{array}\right]=\left[\begin{array}{c}
u^{\prime \prime} c_{\tau}^{m}-\beta p f_{k} v^{\prime \prime} c_{\tau}^{o} \\
u^{\prime \prime} c_{\tau}^{m}
\end{array}\right] d \tau+} \\
{\left[\begin{array}{c}
u^{\prime \prime} c_{p}^{m}-\beta p f_{k} v^{\prime \prime} c_{p}^{o}-\beta f_{k} v^{\prime} \\
u^{\prime \prime} c_{\tau}^{m}
\end{array}\right] d p+\left[\begin{array}{c}
u^{\prime \prime} c_{n}^{m}-\beta p f_{k} v^{\prime \prime} c_{n}^{o} \\
u^{\prime \prime} c_{n}^{m}
\end{array}\right] d n}
\end{gathered}
$$


Assume the determinant of the left hand side matrix is positive, $\Delta>0$, and that $\beta p\left[f_{k h} h^{\prime} v^{\prime}+f_{k} v^{\prime \prime} c_{e}^{o}\right]>0$ and $-u^{\prime \prime} c_{e}^{m}+\delta h^{\prime \prime}<0$. Comparative static results at an interior, stable, steady-state equilibrium are contained in the following propositions.

Proposition 1: Assume $\tau()=\tau$, constant for all $p$ and $n$. Then, economies with higher tax rates, $\tau$, have lower steady-state physical capital stocks and lower private education expenditures if the economy is dynamically efficient.

Proof: $\frac{d k}{d \tau}=\frac{1}{\Delta}\left[-\left[-u^{\prime \prime} c_{e}^{m}+\delta h^{\prime \prime}\right] p \beta f_{k} v^{\prime \prime} c_{\tau}^{o}+\delta h^{\prime \prime} u^{\prime \prime} c_{\tau}^{m}-u^{\prime \prime} c_{\tau}^{m} p \beta\left[f_{k k} h^{\prime} v^{\prime}+f_{k} v^{\prime \prime} c_{e}^{o}\right]\right]<0$

and $\quad \frac{d e}{d \tau}=\frac{u^{\prime \prime} p \beta}{\Delta}\left[c_{\tau}^{m} f_{k k} v^{\prime}-\frac{(1+n) f_{h} h f_{k} v^{\prime \prime}}{p}\left[f_{k}-(1+n)\right]\right]<0$

since $c_{\tau}^{m}<0, c_{\tau}^{o}>0$, and $f_{k}-(1+n)>0$ if the economy is dynamically efficient.

The higher tax rate implies that the income of the middle aged is lower, all else equal, and social security benefits for the old are higher. When agents expect to receive higher benefits they save less. The direct income effect reduces expenditures in all expenditure classes. Thus, all else equal, higher tax rates imply a smaller physical capital stock, a result common in the literature, and a reduction in parent's expenditures on their children's education leading to a smaller human capital stock. This suggests that programs designed to benefit the elderly can hurt the young, both directly by reducing their education, so their human capital, and indirectly by reducing the capital that will be available when they enter the work force. This result clearly shows that social security crowds out the parental input to education.

Proposition 2: Economies in which agents have longer expected lifetimes, higher $p$, have lower physical capital stocks if the sum of the longevity and transfer effects is positive, 
$-\beta f_{k}\left[v^{\prime}+p v^{\prime \prime} c_{p}^{o}\right]>0$ which necessitates a steep tax function, $c_{p}^{o}>0$. Also, they have lower education expenditures if the above conditions hold and consumption while young is increasing in the capital stock, $c_{k}^{m}>0$.

Proof: $\frac{d k}{d p}=\frac{1}{\Delta}\left[-\beta f_{k}\left[-u^{\prime \prime} c_{e}^{m}+d h^{\prime \prime}\right]\left[v^{\prime}+p v^{\prime \prime} c_{p}^{o}\right]+\delta h^{\prime \prime} u^{\prime \prime} c_{p}^{m}-p \beta u^{\prime \prime} c_{p}^{m}\left[f_{k h} h^{\prime} v^{\prime}+f_{k} v^{\prime \prime} c_{e}^{o}\right]\right]<0$ if $-\beta f_{k}\left[v^{\prime}+p v^{\prime \prime} c_{p}^{o}\right]>0$ since $c_{p}^{m}<0$

$$
\frac{d e}{d p}=\frac{\beta u^{\prime \prime}}{\Delta}\left[p c_{p}^{m}\left[f_{k k} v^{\prime}+f_{k} v^{\prime \prime} c_{k}^{o}\right]-f_{k} c_{k}^{m}\left[v^{\prime}+p v^{\prime \prime} c_{p}^{o}\right]\right]<0
$$

if $c_{k}^{m}>0$ and $c_{p}^{o}>0$.

There are several conflicting effects: a positive longevity effect, a negative bequest effect, a negative tax effect on the middle-aged and a positive or negative transfer effect on the old. Higher expected longevity increases the incentive to save to fund a longer retirement. ${ }^{12}$ Higher longevity, however, reduces unintentional bequests, which reduces expected income for middle-aged agents, leading to reductions in saving and parents' expenditures on their children's education. Increased taxes, as a result of longer life expectancy, reduce the middle aged's income, compounding the negative bequest effect, and increase or decrease transfers received when old depending on the slope of the tax function. The longevity, bequest and tax effects together may lead either to higher or lower saving and parental education expenditures. ${ }^{13}$ However, if the transfer effect is large and positive enough to outweigh the longevity effect then

12 We assume that an increase in longevity results in an increase in the length of retirement rather than an increase in the lengths of middle and old age. This is consistent with Hamermesh (1984) who finds that workers who live longer do not work more than their shorter-lived colleagues.

${ }^{13}$ Our results concerning population aging here and below are in contrast to Meijdam and Verbon (1997) since they define population aging as a decrease in the population growth rate, while we define it as an increase in expected lifespan holding the population growth rate constant, or as a decrease in the population growth rate holding the expected lifetime constant. 
the transfer, tax and bequest effects can together lead to lower rates of physical and human capital accumulation: social security crowds out education.

Proposition 3: Economies with higher population growth rates $(n)$ have lower per capita physical capital stocks if the tax rate is fixed so $c_{n}^{o}>0$ and $c_{n}^{m}<0$, and higher human capital stocks if the tax function is flat enough so $c_{n}^{o}>0$ but $c_{n}^{m}>0$ and consumption in middle age is decreasing in the capital stock, $c_{k}^{m}<0$.

Proof: $\frac{d k}{d n}=\frac{1}{\Delta}\left[\left[-u^{\prime \prime} c_{e}^{m}+d h^{\prime \prime}\right]\left[-p \beta f_{k} v^{\prime \prime} c_{n}^{o}\right]+\delta h^{\prime \prime} u^{\prime \prime} c_{n}^{m}-p \beta u^{\prime \prime} c_{n}^{m}\left[f_{k h} h^{\prime} v^{\prime}+f_{k} v^{\prime \prime} c_{e}^{o}\right]\right]<0$

if $c_{n}^{o}>0$ and $c_{n}^{m}<0$;

$$
\frac{d e}{d n}=\frac{\beta p u^{\prime \prime}}{\Delta}\left[c_{n}^{m}\left[f_{k k} v^{\prime}+f_{k} v^{\prime \prime} c_{k}^{o}\right]-f_{k} c_{k}^{m} v^{\prime \prime} c_{n}^{o}\right]>0
$$

if $c_{n}^{o}>0, c_{n}^{m}>0$ and $c_{k}^{m}<0$.

There are again several conflicting effects: a negative family size effect on the middle aged, a positive family size effect on the old, a positive tax effect on the young and a negative transfer effect on the old. Ignoring the tax/transfer effects, physical capital accumulation falls. This is because, for a fixed tax rate, transfers will rise, reducing the incentive to save. If the tax rate is sensitive to changes in the aged-dependency ratio, the tax/transfer effects may increase income when middle-aged and when old. Both effects increase lifetime income, so increase the incentive to invest in education. This suggests that a reduction in the aged-dependency ratio, and thereby the social security tax rate, may allow education to crowd in. 


\section{Growth}

In this model parents fund their children's education, and in so doing plant the seeds for growth. This theoretical position is supported by Barro and Lee's (1993) empirical findings of a positive relationship between educational attainment and economic growth. To examine economic growth we must impose functional form restrictions. We assume that

$$
\begin{aligned}
& U(t)=\ln \left(c_{t}(t+1)\right)+\beta p(t) \ln \left(c_{t}(t+2)\right)+\delta(1+n(t+1)) \ln (e(t+1)) \\
& Y(t+1)=A K(t+1)^{\alpha} H(t+1)^{1-\alpha}
\end{aligned}
$$

so $h(e(t+1))=e(t+1)$. Under these functional form assumptions, the conditions for growth are established in proposition 4.

Proposition 4: If $U(t)=\ln \left(c_{t}(t+1)\right)+\beta p(t) \ln \left(c_{t}(t+2)\right)+\delta(1+n(t+1)) \ln (e(t+1))$ and $Y(t+1)=A K(t+1)^{\alpha} H(t+1)^{1-\alpha}$, then for $A$ large enough, the economy will exhibit balanced growth.

Proof: Define

$$
g(t+1)=\frac{\left[(1-\alpha)\left(1-\tau\left(\frac{p(t-1)}{1+n(t)}\right)+(1-p(t-1)) \alpha\right]\right.}{\left[(1+n(t+1))(1+\phi(t+1))+\frac{\phi(t+1)}{\delta}\right]} A \phi(t)^{1-\alpha}
$$

and

$$
\phi(t)=\left[1+\tau\left(\frac{p(t-1)}{1+n(t)}\right) \frac{(1-\alpha)}{\alpha p(t-1)}\right] \frac{\delta(1+n(t))}{\beta p(t-1)} .
$$

From equations (8) and (9) and under the functional form assumptions

$$
e(t+1)=\phi(t+1) k(t+2) .
$$

Substitute (13) and (13) lagged one period into (8) to yield

$$
k(t+2)=g(t+1) k(t+1) .
$$


This economy will exhibit balanced growth if $g(t+1)>1$ for all $t$, which will be satisfied for $A$ large enough.

We now examine the effects of demographic shifts on economic growth and social welfare. We conduct three distinct simulation experiments: a baby- boom, a sustained decrease in the population growth rate, and a sustained increase in the aged-dependency ratio. In each of these exercises we are careful to analyze the transitional effects of the changes on education expenditures, physical capital accumulation and social welfare. In each of our experiments we examine two policy regimes. The first, Regime A, holds the social security tax rate constant; this holds the cost of the program as a percentage of GNP fixed. The second, Regime B, changes the tax as dictated by the tax function; this increases transfers as the period of retirement lengthens, and decreases the tax rate as the aged-dependency ratio falls.

The simulations use a calibrated version of the model in which many of the parameters chosen reflect the empirical findings of previous authors. Details of the calibration exercise are found in the appendix. The simulations begin with arbitrary starting values for $e(1)$ and $k(2)$ and a growth path is generated given the initial parameter values. Then the simulation is repeated with starting values on the balanced growth path. In each experiment the simulation begins on the baseline growth path and stays there unperturbed for the first four periods. In period five the system is perturbed and the economy is observed over the remaining periods in the simulation run. The tables can be read as follows. The period represents the date of birth of a generation. So, in Table 1, for example, the column headed by 4 lists economic activity when the members of generation 4 are middle aged: education expenditures per (generation 5) child, education as a percentage of GNP in period 5, transfers to the members of generation 3 as a percentage of GNP in period 5, saving as a percentage of GNP in period 5, output per worker in period 5, lifetime utility of a member of generation 4, and annualized growth rate of output between generations 4 and 5. 
To simulate a baby boom we set $n(t)$ at its baseline level for periods 1 - 4 . In period 5 we increase the population growth rate by $10 \%$. In period 6 and in all subsequent periods, $n(t)$ returns to its initial value. The baby boom forces the economy onto a lower growth path, while benefiting the parents of the boomers (generation 4) in both tax regimes. During the baby-boom generation, the per child education expenditure falls, although total education expenditures rise. Saving rises, but the additional capital is insufficient to offset the reductions in education, so baby-boomers have lower expected lifetime income than their parents enjoyed. This loss of income is adequate to force the economy onto a lower growth path, but one with the same rate of balanced growth, even when the tax rate adjusts in response to the new lower aged-dependency ratio. From the perspective of the parents of the baby-boomers, those born at date 4, the preferred tax regime holds taxes fixed, since this nets them the highest transfers, but reduces their incentive to save. This reduced incentive to save, as a result of the social security system, indirectly hurts their children by leaving them with less capital to work with thereby reducing the value of their education. Thus the boomers and their progeny would prefer the aged-dependency ratio sensitive tax as this would cause the boomers to face a lower tax rate, save more, and give their children a better start in life. See Table 1.

To simulate a sustained decrease in the population growth rate we reduce $n(5)$ to $90 \%$ of the baseline growth rate. This lower population growth rate pushes the economy onto a higher growth path with a higher rate of economic growth. This is because the parents of the initial smaller generation increase per child education expenditures, and in regime A save more, increasing the capital with which their children will work. In both regimes these children face an expected lifetime income higher than the baseline when they reach middle age, and so they endow each of their children with more education and, in tax regime A, save more. The positive impact of the higher education expenditures soon generates an increase in economic growth in both regimes and individual well-being in regime A relative to the baseline. In this scenario all generations, save the first with the smaller family size who prefer an aged-dependency ratio 
sensitive tax rate, agree that the best tax regime is that in which the social security tax is held fixed, since by holding the tax rate constant social security is prevented from crowding out education. In this tax regime the growth effects of the decline in population growth are strongest, but these are effects from which the first generation does not benefit. See Table 2 .

The long-run result of lower population growth found here differs from the results of the Solow growth model with exogenous technological progress. There, output per worker grows at the rate of technological progress and is independent of the growth rate of the labor force. Here, in contrast, parents respond to the lower population growth rate by increasing expenditures on each child's education and saving more, at the per child level, which generates the intuitive and empirically valid result that each child is then endowed with more human and physical capital, thus increasing the rate of technological progress. This gives a decrease in the population growth rate both a positive level effect, as in the Solow model, and a positive trend growth effect.

To simulate the increase in the aged-dependency ratio to about that projected for 2040, the probability of living throughout old age is doubled in period 5. When the aged-dependency ratio rises, holding the tax rate constant, agents save more to fund their longer lives and to compensate for the loss of social security transfers. This leads them to reduce per child education expenditures. However, their higher rate of saving more than compensates their children for the reallocation of resources away from education, leaving their children better off financially than in the baseline. Thus, the economy is placed on a higher growth path with a higher rate of balanced growth. If taxes are not held constant and rise with the aged-dependency ratio, tax regime $\mathrm{B}$, the disincentives to saving are heightened. In this regime it is possible that, after tax, the children of the initial generation of longer-lived agents will spend less on each of their children's education and will not save enough to make up the difference, forcing the economy onto a lower growth path with a substantially lower balanced growth rate of $1.6 \%$ annually in Regime $\mathrm{B}$, rather than $2.5 \%$ in the baseline, or $2.9 \%$ annually when the tax rate is held constant in Regime A. This result suggests that the effects on long-term growth and on social welfare of the current 
Congressional practice of raising Social Security taxes as the population ages, using the ageddependency ratio as a guide, could be misguided, although popular among older constituents, as it crowds out education and weakens the incentive to save. See Table 3.

\section{Conclusion}

In this paper we have developed a model in which the education of the young and the financial support of the old interact. In the absence of exogenous technological change, we find that population aging may engender intergenerational conflict since the most preferred tax policy of the initial generation, higher social security taxes and transfers, is generally not that of subsequent generations because social security crowds out education, a key to economic growth and improved social welfare. Further, social welfare considerations may get lost when it is the generosity of the program and not the welfare of either current or future beneficiaries that takes center stage when adjustments are considered. This is because the passage of time magnifies the crowding out effects, and planners' time horizons are often short.

Before policy recommendations can be made, four caveats, one strengthening and three weakening these results, should be mentioned. First, increases in social security benefits today benefit those already retired and those who are soon to retire. Thus as the population ages the percentage of the voting population in favor of social security benefit, therefore tax, increases will rise. This situation is both acute and politically volatile in countries like Italy, Switzerland, Germany, and the United States that expect to see aged-dependency ratios in excess of .4 by the year 2030. Second, our model does not take into account uncertainty concerning bequest receipt. Weil (1993) shows that when bequests are uncertain saving (and, implicitly, in the framework of our model, education expenditures) falls less fast as the population ages than in models in which bequests are treated as certain. Thus, the effects of population aging found in our model may be overstated. Third, the old may save, and thus increased expected life span may increase the savings accumulated while old. Finally, when average life span increases agents may choose to 
work longer, leaving the aged-dependency ratio fixed thereby nullifying the effects of population aging. However, as the populations of the US and European countries have aged, absent changes in laws governing Old Age Pensions and Social Security, the proportion of the aged working has actually decreased, increasing rather than decreasing the effects of aging on economic behavior.

Overall our model sounds a note of caution. In caring for our current aged we should not short change either our current young or our future aged. This will require policy makers to change their way of thinking, and to recognize that a more generous program does not necessarily imply greater social welfare. Having realized this, they may make decisions that, while for the greater good, may run counter to the wishes of some of their most vocal constituents, which is, at best, a thankless task. 


\section{References}

Aaron, H. J., and G. Burtless, 1989, "Fiscal policy and the dynamic inconsistency of social security forecasts," American Economic Review 79, 91-6.

Allais, M., 1947, Economie et Interet, Imprimerie Nationale, Paris.

Altonji. J. G., F. Hayashi, and L. J. Kotlikoff, 1992, "Is the extended family altruistically linked? Direct tests using micro data," American Economic Review 82, 1177-98.

Auerbach, A. J., and L. J. Kotlikoff, 1987, Dynamic Fiscal Policy, New York: Cambridge University Press.

Auerbach, A. J., and L. J. Kotlikoff, 1990, "Demographics, fiscal policy, and U.S. saving in the 1980s and beyond," in Tax Policy and the Economy, vol. 4., L. Summers, ed., Chicago: Chicago University Press.

Auerbach, A. J., L. J. Kotlikoff, and D. N. Weil, 1992, "The increasing annuitization of the elderly - estimates and implications for intergenerational transfers, inequality, and national saving," NBER Working Paper No. 4182.

Barro, R. J., 1974, "Are government bonds net wealth?" Journal of Political Economy 82, 10951117.

Barro, R. J., and J. Lee, 1993, "International comparisons of educational attainment," NBER Working Paper No. 4349.

Black, S. E., 1998, "Measuring the value of better schools," Federal Reserve Bank of New York Economic Policy Review, 87-94

Board of Trustees, Federal Old-Age and Survivors Insurance and Disability Insurance Trust Fund, 1993, The1993 Annual Report of the Federal Old-Age and Survivors Insurance and Disability Insurance Trust Fund, Washington, D.C.: USGPO.

Boldrin, M., 1993, "Public education and capital accumulation," J.L. Kellogg Graduate School of Management, Northwestern University, Discussion Paper No. 1017.

Borsch-Supan, A., 1993, "Aging in Germany and the US: international comparisons," NBER Working Paper No. 4530.

Boskin, M. J., 1988, "Tax policy and economic growth: lessons from the 1980s," Journal of Economic Perspectives 2, 71-9.

Boskin, M. J., L. J. Kotlikoff, D.J. Puffert, and J.B. Shoven, 1987, "Social security: a financial appraisal across and within generations," National Tax Journal 40, 19-34.

Caballé, J., 1995, "Endogenous growth, human capital, and bequests in a life-cycle model," Oxford Economic Papers 47, 156-81.

Cigno, A., and F. Rosati, 1996, "Jointly determined saving and fertility behaviour: Theory, and estimates for Germany, Italy, UK and USA," European Economic Review 40, 1561-89. 
Cremer, H., D. Kessler, and P. Pestieau, 1992, "Intergenerational transfers within the family," European Economic Review 36, 1-16.

Congleton, R. D. and W. F. Shughart II, 1990, "The growth of social security: electoral push or political pull?" Economic Inquiry 28, 109-32.

Council of Economic Advisors, 1994, Economic Indicators, Washington, D.C.: United States Government Printing Office.

DeLong, J. B., and L. Summers, 1991, "Equipment investment and economic growth," Quarterly Journal of Economics 106, 445-502.

Diamond, P. A., 1965, "National debt in a neoclassical growth model," American Economic Review 55, 1126-50.

Diamond, P.A., 1977, "A framework for social security analysis," Journal of Public Economics $8,275-98$.

Ehrlich, I., and F. T. Lui, 1991, "Intergenerational trade, longevity, and economic growth," Journal of Political Economy 99, 1029-59.

Glomm, G., and B. Ravikumar, 1992, "Public versus private investment in human capital: endogenous growth and income inequality," Journal of Political Economy 100, 818-34.

Hamermesh, D. S., 1984, "Life cycle effects on consumption and retirement," Journal of Labor Economics.

Hamermesh, D. S. and P. L. Menchik, 1987, "Planned and unplanned bequests," Economic Inquiry 25, 55-66.

Hanushek, E. A., 1997, "Assessing the effects of school resources on student performance: An update," Educational Evaluation and Policy Analysis 19, 141-64.

Hubbard, R. G., and K. L. Judd, 1987, "Social security and individual welfare: precautionary saving, borrowing constraints, and the payroll tax," American Economic Review 77, 63046.

Hurd, M. D., 1989, “Mortality risk and bequests,” Econometrica 57, 779-813.

Hurd, M. D., 1990, "Research on the elderly: economic status, retirement and consumption and saving," Journal of Economic Literature 28, 565-637.

Hurd, M. D., 1995, "Using subjective survival probabilities in life cycle models," mimeo., Department of Economics, SUNY Stony Brook.

Imrohoroglu, A., S. Imrohoroglu, and D. Joines, 1992, "A life cycle analysis of social security," mimeo, University of Southern California.

Jones, L. and R. Manuelli, 1992, "Finite lifetimes and growth," Journal of Economic Theory 58, 171-97. 
King, R. G., and S. Rebelo, 1990, "Public policy and economic growth: developing neoclassical implications," Journal of Political Economy 98, S126-50.

Kotlikoff, L.J., 1987, "Social security", The New Palgrave Dictionary of Economics, Vol. 4, P. Newman, M. Milgate, and J. Eatwell, eds., 413-18.

Kydland, F., and E. Prescott, 1992, "Time to build and aggregate fluctuations," Econometrica 50, 1345-70.

Laitner, J., and F.T. Juster, 1996, "New evidence on altruism: A study of TIAA-CREF retirees," American Economic Review 86, 893-908.

Lucas, R., 1988, "On the mechanics of economic development," Journal of Monetary Economics 21, 3-42.

Madison, A., 1987, "Growth and slowdown in advanced capitalist economies," Journal of Economic Literature 25, 649-98.

Meijdam, L., and H. Verbon, 1997, "Aging and public pensions in an overlapping- generations model," Oxford Economic Papers, 49, 29-42.

Nishimura, K., and J. Zhang, 1992, "Pay-as-you-go public pensions with endogenous fertility," Journal of Public Economics 48, 239-58.

Nishimura, K., and J. Zhang, 1995, "Sustainable plans of social security with endogenous fertility," Oxford Economic Papers 47, 182-94.

Poterba, J.M., and L.H. Summers, 1986, "Public policy implications of declining old-age mortality," in Work, Health and Income among the Elderly, G. Burtless, ed., Washington, D.C.: Brookings Institution.

Prescott, E., 1986, "Theory ahead of business cycle measurement," Federal Reserve Bank of Minneapolis Quarterly Review 10, 9-22.

Rebelo, S., 1991, "Long-run policy analysis and long-run growth," Journal of Political Economy 99, 500-21.

Reimers, C.W., 1992, "US social security system" The New Palgrave Dictionary of Money and Finance, Vol. 3, P. Newman, M. Milgate, and J. Eatwell, eds., 740-43.

Saint-Paul, G., 1992, "Fiscal policy in an endogenous growth model," Quarterly Journal of Economics 107, 1243-59.

Sala-i-Martin, X., 1992, "Pensions," Yale University Economic Growth Center Discussion Paper No. 657.

Samuelson, P., 1958, "An exact consumption-loan model of interest with or without the social contrivance of money," Journal of Political Economy 66, 467-82. 
Social Security Advisory Council, 1996, Report of the 1994-1996 Advisory Council on Social Security, Volumes I and II, Washington, D.C.: Social Security Administration.

Weaver, C.L., 1992, "Social security in aging societies," Population and Development Review 12, Supplement, 273-95.

Weil, D. N., 1993, "Intergenerational transfers, aging and uncertainty," NBER Working Paper No. 4477.

Wildasin, D.E., 1991, "The marginal cost of public funds with an aging population," Population Economics 4, 111-35.

Zhang, J., 1995, "Social security and endogenous growth," Journal of Public Economics 58, 185213. 


\section{Appendix}

\section{Choice of Parameter Values}

For our baseline simulations we take a generation to be twenty years in length and set $\alpha=.3, \delta=.1$ and $\beta=.67=.98^{20}$. Further, we let $n(t)=.22\left(=(1.01)^{20}-1\right)$ and $p(t-1)=.26108$, since this combination yields the current aged-dependency ratio of slightly less than .214 (1993 Annual Report of the Federal OASDI Trust Fund). Our selection of $\alpha$ is a compromise between the high a value estimated by Prescott (1986) for capital's share of national income, and the lower estimates made by the Council of Economic Advisors (1994) which ranged from $\alpha=.24$ in 1982 to $\alpha=.27$ for several years in the late 1980 s and early 1990 s. We found that the choice of $\delta$ had little effect on the simulation, so we assumed a low value: parent's do not dote on their children.

Our value of $\beta$ is based on the single period discount rate found by Auerbach and Kotlikoff (1987) of .98, and is similar to that found by Kydland and Prescott (1992) of .96. Since the agents in our model plan over generations that span 20 years, we discount the future by $.98^{20}$.

For those simulations in which the tax rate is constant we set $\tau=.09$ which generates a social security replacement rate, the benefit to wage ratio, of .42, the current rate for the average wage earner according the Social Security Office of the Chief Actuary. For those simulations in which the tax function is a function of the aged-dependency ratio, $\tau=.2[\mathrm{p}(\mathrm{t}-1) /(1+\mathrm{n}(\mathrm{t}))]+$ $1.0306577[p(t-1) /(1+n(t))]$, where the constants are chosen so that the tax rate equals .09 at the current aged-dependency ratio. This tax function is convex in the aged-dependency ratio and was chosen to be consistent with the findings of Poterba and Summers (1986). While this baseline tax rate appears to be low, at about one percentage point below the current OAS tax rate of $10.2 \%$, it reflects the fact that the Social Security System is currently running a surplus so that all tax revenues are not distributed. Given these parameter values, the productivity constant $\mathrm{A}$ is calculated to guarantee an annual growth rate of $2.5 \%$ (a generational growth rate of .63862).

Depending upon the historical period of interest, the literature presents many possible choices for the rate of growth of the U.S. economy. Madison (1987) finds the average annual compound growth rates of GDP in the U.S. to be $4.2 \%$ from $1870-1973$, and $2.3 \%$ from 1973 1984. In addition, he finds the annual rate of GDP growth per person employed to be $4.25 \%$ from 1950-1973 and 1.72\% from 1973-1984. In contrast, DeLong and Summers (1991) find the annual growth of GDP per worker to be 1.33\% from 1960 - 1985. Finally, Boskin (1988) cites the following annual growth rates of real GNP: 3.7\% from 1948-1973, 2.2\% from 1973 - 1981, and $3.3 \%$ from $1981-1988$. We choose the growth rate of $2.5 \%$ as being a compromise among the findings of the various studies. 


\begin{tabular}{|c|c|c|c|c|c|c|}
\hline & & $\begin{array}{l}\text { ble } 1 \\
\text { /-boom }\end{array}$ & & & & \\
\hline & Periods & 4 & 5 & 6 & 7 & 8 \\
\hline & $\rightarrow$ & & & & & \\
\hline & Regime $\downarrow$ & & & & & \\
\hline Education per child $(t+1)$ & Baseline & 169.927 & 278.444 & 456.264 & 747.641 & 1225.10 \\
\hline & Regime & 169.629 & 276.457 & 453.006 & 742.303 & 1216.35 \\
\hline & Regime & 169.458 & 277.736 & 455.103 & 745.739 & 1221.98 \\
\hline & & & & & & \\
\hline Education $(t+1) / G N P(t+1)$ & Baseline & .0859 & .0859 & .0859 & .0859 & .0859 \\
\hline & Regime & .0873 & . 0859 & .0859 & 0859 & .0859 \\
\hline & $\begin{array}{l}\text { A } \\
\text { Regime }\end{array}$ & .0875 & .0861 & .0859 & .0859 & .0859 \\
\hline & & & & & & \\
\hline SS Transfers & Baseline & 0.063 & 0.0630 & 0.063 & 0.063 & 0.063 \\
\hline & Regime & 0.063 & 0.0630 & 0.063 & 0.063 & 0.063 \\
\hline & & 0.063 & 0.0616 & 0.063 & 0.063 & 0.063 \\
\hline & B & & & & & \\
\hline Saving $(t+1) / G N P(t+1)$ & Baseline & 0.0683 & 0.0683 & 0.0683 & 0.0683 & 0.0683 \\
\hline & Regime & 0.0682 & 0.0683 & 0.0683 & 0.0683 & 0.0683 \\
\hline & $\begin{array}{l}\text { A } \\
\text { Regime }\end{array}$ & 0.0687 & 0.0684 & 0.0683 & & 0.0683 \\
\hline & & & & & & \\
\hline Output(t+1)/Worker & Baseline & 2412.22 & 3952.70 & 6476.95 & 10613.2 & 17391.0 \\
\hline & Regime & 2412.22 & 3924.48 & 6430.71 & 10537.5 & 17266.9 \\
\hline & $\begin{array}{l}\text { A } \\
\text { Regime }\end{array}$ & 2412.22 & 3934.89 & & 10586.2 & 17346.8 \\
\hline & & & & & & \\
\hline Utility(t) & Baseline & 9.44063 & 10.0811 & 10.7216 & 11.3621 & 12.0026 \\
\hline & Regime & 9.45177 & 10.0718 & 10.7123 & 11.3528 & 11.9933 \\
\hline & $\begin{array}{l}\text { A } \\
\text { Regime }\end{array}$ & 9.44905 & 10.0835 & 10.7183 & 11.3588 & 11.9993 \\
\hline & & & & & & \\
\hline Annualized Growth (\%) & Baseline & 2.500 & 2.500 & 2.500 & 2.500 & 2.500 \\
\hline & $\begin{array}{l}\text { Regime } \\
\text { A }\end{array}$ & 2.500 & 2.399 & 2.500 & 2.500 & 2.500 \\
\hline
\end{tabular}




\begin{tabular}{|l|l|r|r|r|r|r|}
\hline & $\begin{array}{l}\text { Regime } \\
\mathrm{B}\end{array}$ & 2.500 & 2.477 & 2.510 & 2.500 & 2.500 \\
\hline
\end{tabular}




\begin{tabular}{|c|c|c|c|c|c|c|}
\hline & $10 \%^{\top}$ & $\begin{array}{l}\text { ble } 2 \\
\text { cline in }\end{array}$ & & & & \\
\hline & Periods & 4 & 5 & 6 & 7 & 8 \\
\hline & $\rightarrow$ & & & & & \\
\hline & Regime & & & & & \\
\hline Education per child $(t+1)$ & Baseline & 169.927 & 278.444 & 456.264 & 747.641 & 1225.10 \\
\hline & Regime A & 170.234 & 280.982 & 463.779 & 765.498 & 1263.50 \\
\hline & Regime B & 170.402 & 279.906 & 459.780 & 755.245 & 1240.58 \\
\hline Education $(\mathrm{t}+1) / \mathrm{GNP}(\mathrm{t}+1)$ & Baseline & .0859 & .0859 & .0859 & .0859 & .0859 \\
\hline & Regime A & .0845 & .0845 & .0845 & .0845 & .0845 \\
\hline & Regime B & .0846 & .0845 & .0858 & .0845 & .0845 \\
\hline SS & Baseline & 0.063 & 0.0630 & 0.0630 & 0.0630 & 0.0630 \\
\hline & Regime A & 0.063 & 0.0630 & 0.0630 & 0.0630 & 0.0630 \\
\hline & Regime B & 0.063 & 0.0651 & 0.0651 & 0.0651 & 0.0651 \\
\hline Saving $(t+1) / G N P(t+1)$ & Baseline & 0.0683 & 0.0683 & 0.0683 & 0.0683 & 0.0683 \\
\hline & Regime A & 0.0685 & 0.0685 & 0.0685 & 0.0685 & 0.0685 \\
\hline & Regime B & 0.0677 & 0.0675 & 0.0675 & 0.0675 & 0.0675 \\
\hline Output(t+1)/Worker & Baseline & 2412.22 & 3952.70 & 6476.95 & 10613.2 & 17391.0 \\
\hline & Regime A & 2412.22 & 3981.52 & 6571.76 & 10847.1 & 17903.9 \\
\hline & Regime B & 2412.22 & 3970.56 & 6522.13 & 10713.4 & 17598.1 \\
\hline Utility(t) & Baseline & 9.44063 & 10.0811 & 10.7216 & 11.3621 & 12.0026 \\
\hline & Regime A & 9.42944 & 10.0783 & 10.7271 & 11.3759 & 12.0247 \\
\hline & Regime B & 9.43225 & 10.0691 & 10.7117 & 11.3543 & 11.9968 \\
\hline Annualized Growth (\%) & Baseline & 2.500 & 2.500 & 2.500 & 2.500 & 2.500 \\
\hline & Regime A & 2.500 & 2.537 & 2.537 & 2.537 & 2.537 \\
\hline & Regime B & 2.500 & 2.523 & 2.513 & 2.513 & 2.513 \\
\hline
\end{tabular}




\begin{tabular}{|c|c|c|c|c|c|c|}
\hline Douk & ing of the $A c$ & $\begin{array}{l}\text { le } 3 \\
\text { d-Depe }\end{array}$ & dency & atio & & \\
\hline & Periods $\rightarrow$ & 4 & 5 & 6 & 7 & 8 \\
\hline & Regime & & & & & \\
\hline Education $(t+1)$ per child & Baseline & 169.927 & 278.444 & 456.264 & 747.641 & 1225.100 \\
\hline & Regime A & 169.927 & 247.472 & 434.927 & 764.376 & 1343.380 \\
\hline & Regime B & 169.927 & 265.339 & 363.254 & 497.302 & 680.816 \\
\hline Education $(t+1) / G N P(t+1)$ & Baseline & .0859 & .0859 & .0859 & .0859 & .0859 \\
\hline & Regime A & .0859 & .0764 & .0694 & .0694 & .0694 \\
\hline & Regime B & .0859 & .0819 & .0621 & .0621 & .0621 \\
\hline SS & Baseline & 0.063 & 0.063 & 0.0630 & 0.0630 & 0.0630 \\
\hline & Regime A & 0.063 & 0.063 & 0.0630 & 0.0630 & 0.0630 \\
\hline & Regime B & 0.063 & 0.063 & 0.1918 & 0.1918 & 0.1918 \\
\hline Saving $(t+1) / G N P(t+1)$ & Baseline & 0.0683 & 0.0683 & 0.0683 & 0.0683 & 0.0683 \\
\hline & Regime A & 0.0683 & 0.1562 & 0.1420 & 0.1420 & 0.1420 \\
\hline & Regime B & 0.0683 & 0.1055 & 0.0800 & 0.0800 & 0.0800 \\
\hline Output(t+1)/Worker & Baseline & 2412.22 & 3952.70 & 6476.95 & 10613.2 & 17391.0 \\
\hline & Regime A & 2412.22 & 3952.70 & 76440.4 & 13434.2 & 23610.4 \\
\hline & Regime B & 2412.22 & 3952.70 & 7134.61 & 9767.4 & 13371.8 \\
\hline Utility(t) & Baseline & 9.44063 & 10.0811 & 10.7216 & 11.3621 & 12.0026 \\
\hline & Regime A & 9.44063 & 11.3811 & 12.2110 & 13.0410 & 13.8709 \\
\hline & Regime B & 9.44063 & 11.5969 & 12.0592 & 12.5215 & 12.9839 \\
\hline Annualized Growth (\%) & Baseline & 2.500 & 2.500 & 2.500 & 2.500 & 2.500 \\
\hline & Regime A & 2.500 & 2.500 & 3.353 & 2.860 & 2.860 \\
\hline & Regime B & 2.500 & 2.500 & 2.997 & 1.583 & 1.583 \\
\hline
\end{tabular}

